Volume 3 Nomor 1, Maret 2021, Halaman 17 - 33.

\title{
Usaha Peningkatan Pemasaran Keripik Pisang NVN Melalui Desain Produk dan Online Shop
}

\author{
Nunung Nurhayati \\ Prodi Manajemen Fakultas Ekonomi Universitas Wiralodra \\ Email: nunungnurhayati@unwir.ac.id
}

\begin{abstract}
Abstrak
Pandemi Covid-19 ini sangat berpengaruh terhadap perekonomian. Hal ini sangat terlihat dari berkurangnya daya beli masyarakat pada produk - produk makanan ringan. Usaha Kecil Menegah (UKM) sangat merasakan dampak ini. Dengan demikian perlu adanya suatu perubahan cara pemasaran bagi pelaku UKM. Tujuan pengabdian ini adalah membantu UKM Keripik Pisang NVN dalam hal pemasaran. Metode yang digunakan adalah metode partisipatif. Tim melakukan perubahan pada pelabelan produk dan membantu memasarkan secara online. Hasil pengabdian ini adalah perbaikan desain produk dan pemasaran produk secara online Keripik Pisang NVN. Selain itu produk juga dipasarkan melalui offline dengan cara didistribusikan ke tempat - tempat yang strategis dan swalayan sehingga meningkatkan pendapatan UKM.
\end{abstract}

Kata Kunci : Usaha Kecil Menengah, Keripik Pisang, Desain Produk, Pemasaran.

\begin{abstract}
Abtract
The Covid-19 pandemic has had a major impact on the economy. This can be seen from the reduced purchasing power of people for snack products. Small and Medium Enterprises (SMEs) are particularly affected by this. For that there needs to be a change in the way of marketing for SMEs. The purpose of this service is to help the Banana Chips SME NVN in terms of marketing. The method used is a participatory method. The team made changes to product labeling and helped market it online. The result of this dedication is the improvement of product design and online product marketing of the NVN Banana Chips. In addition, products are also marketed offline by distributing them to strategic places and supermarkets, thereby increasing the income of SMEs.

Keywords: Small and Medium Enterprises, Banana Chips, Product Design, Marketing.
\end{abstract}

DOI: https://doi.org/10.31943/abdi.v3i1.34

\section{A. Pendahuluan}

Wabah Covid-19 yang memasuki Indonesia sejak Maret lalu, mengakibatkan banyak sektor yang beroperasi harus segera menyesuaikan diri demi keamanan dan kesehatan setiap masyarakat. Tak terkecuali institusi pendidikan dan kegiatannya harus disesuaikan pula. 
Jika di tahun-tahun sebelumnya pengabdian yang dilakukan oleh mahasiswa bebas memilih di mana akan melaksanakan Program Kerja Lapangan (PKL) sesuai keinginan mahasiswa dengan persetujuan fakultas, maka di tahun ini pihak fakultas yang menentukan tempat dan kelompok mahasiswa yang akan melaksanakan PKL. Pada PKL ini fakultas mewajibkan untuk setiap mahasiswa melaksanakan PKL di tempat-tempat yang sudah direkomendasikan, yaitu jenis Industri Kecil dan Menegah (IKM). Fakultas memilih IKM karena IKM adalah usaha yang mampu mendongkrak perekonomian di masyarakat dengan kemampuan ekonomi menengah kebawah (Maya \& Yohanna, 2018)(Kore \& Septarini, 2018; Ratnasari \& Kirwani, 2013).

IKM sendiri merupakan istilah lain dari UMKM (Usaha Mikro, Kecil, dan Menengah) yang digunakan dalam judul program PKL pada tahun ini. Secara tidak langsung, fokus tim pengabdian pada kegiatan PKL di tahun ini yaitu untuk membantu, menyokong, dan membangkitkan salah satu sektor ekonomi yang paling berpotensi untuk berkembang yaitu IKM-IKM yang tersebar di seluruh Kabupaten Indramayu.

IKM di Indramayu sangatah banyak, IKM yang menjadi mitra pada kegiatan ini adalah IKM Keripik Pisang NVN. IKM ini didirikan oleh Ibu Novi Rahayu dan beralamat di jalan Bondol Selatan, RT 002 / RW 002, Kel. Brondong, Kec. Pasekan, Kab. Indramayu, Prov. Jawa Barat. Pada awalnya usaha pembuatan keripik pisang merupakan usaha yang tergabung pada IKM LK Buah Ibu Kasturi yang berlokasi di Jl. Raya Pawidean, Desa Pawidean, Kec. Jatibarang, Kabupaten Indramayu, Jawa Barat. Di IKM inilah ibu Novi Rahayu, yang merupakan anak dari pemilik LK Buah Ibu Kasturi, yang membawahi kegiatan produksi keripik pisang. Untuk alasan yang tidak disebutkan, sehingga sejak tahun 2014, ibu Novi Rahayu memutuskan untuk mendirikan IKM sendiri yang beliau beri nama Keripik Pisang NVN dibawah kepemilikannya sendiri. Dengan itu, beliau berusaha untuk segera mendapatkan izin usaha, sertifikasi halal MUI, dan sertifikat uji nutrisi, yang beberapa telah beliau peroleh. Kegiatan produksi keripik pisang berjalan mulus, namun masih menemukan beberapa hambatan.

Salah satu hambatannya adalah wabah Covid-19 yang menerpa baru-baru ini, menyebabkan wirausahawan kehilangan banyak pemasukan (Ihza, 2020; Rosita, 
2020), termasuk usaha keripik pisang ini. Hal ini diperparah dengan anak ibu Novi yang jatuh sakit. Memaksa ibu Novi Rahayu untuk mengurangi kuantitas dan jam produksi lebih dari separuhnya. Saat ini, beliau hanya memproduksi tidak lebih dari 500 bal keripik pisang dan hanya akan menerima pesanan dalam jumlah yang sedikit. Beberapa hasil dari wawancara terkait dengan permasalahan mitra adalah sebaagai berikut.

1. Kekurangan tenaga kerja. IKM Keripik Pisang NVN faktanya hanya dijalankan oleh 2 orang, yaitu ibu Novi Rahayu dan suaminya. Beliau bertugas untuk menerima pesanan, mengemas dan memasarkan produknya. Sedangkan suaminya bertugas untuk memperoleh bahan baku dan mengolahnya. Beliau mengatakan semua proses tersebut dilaksanakan pada hari yang sama, agar menghasilkan keripik pisang yang baik.

2. Kekurangan modal. Ibu Novi Rahayu mengatakan pada awalnya memperoleh modal usaha dari produk KUR BRI. Namun karena prosesnya rumit dan cicilannya besar, maka beliau berhenti menggunakan produk bank tersebut. Sebagai gantinya, beliau memperoleh pinjaman dengan menggadaikan surat berharganya (izin usaha dan BPKB) kepada pihak Pegadaian dengan cicilan yang menurutnya lebih ringan. Namun kekurangannya adalah pinjaman yang beliau peroleh tidaklah banyak. Dikarenakan modal yang dimiliki terbatas, maka produk yang dihasilkan pun terbatas.

3. Jaringan pemasaran yang kecil. Ibu Novi Rahayu mengatakan pada awalnya produk keripik ini mampu menembus pasar lokal, nasional bahkan internasional. Produk keripik ini pernah diekspor ke Singapura, namun ketika masih di bawah merek IKM LK Buah. Karena kekurangan tenaga kerja dan terjadinya wabah Covid-19 ini maka secara perlahan, jaringan pemasarannya mengecil. Hanya pada lingkup lokal saja saat ini.

4. Desain label keripik yang kurang menarik. Menurut tim pengabdian, desain label yang digunakan kurang menarik. Hanya sebatas tulisan dan mereknya saja. Perlu dibuat desain yang lebih berwarna dan sedikit banyak bisa menarik minat beli masyarakat.

5. Menggunakan alat modern namun kurang memadai. Dalam pengemasan keripik sudah menggunakan alat pres dan timbangan digital, namun kurang 


\section{ABDI WIRALODRA}

JURNAL PENGABDIAN KEPADA MASYARAKAT
ISSN 2656-5501 (Print)

ISSN 2714-8041 (Online)

memadai. Pasalnya ketika tim pengabdian membantu mengemas keripik tersebut ternyata alat pres sudah tidak bisa berfungsi dengan baik, seperti kurang panas dan mati dengan sendirinya. Sedangkan ukuran timbangannya terlalu kecil untuk produksi banyak dan juga tidak bisa berfungsi dengan baik.

Berdasarkan permasalahan - permasalahan tersebut di atas, maka tim pengabdian berusaha untuk memberikan solusi untuk memecahkan permasalahan tersebut. Menurut Philip Kotler, pemasaran adalah suatu proses manajerial antar dua individu atau kelompok untuk mendapatkan apa yang mereka butuhkan dengan menciptakan, menawarkan, dan mempertukarkan produk yang bernilai kepada pihak lain (Widyastuti, 2017).

Istilah bauran pemasaran (marketing mix) sangat dikenal dalam strategi pemasaran. Bauran pemasaran merupakan cara seorang pengusaha dapat mempengaruhi konsumen melalui perencanaan dan pengawasan yang matang serta perlu dilakukan beberapa tindakan yang konkrit untuk mengejar tujuan pemasaran(Sari \& Kusumadewi, 2016). Terkait dengan bauran pemasaraan, pengusaha dapat melakukan beberapa tindakan berikut :

a) Produk (Product)

Produk adalah pandangan konsumen terhadap hasil produksi dari produsen (Pratiwi \& Suriani, 2017). Produk yang ditawarkan oleh produsen adalah keripik pisang. Keripik pisang ini terdiri dari berbagai varian rasa, mulai dari rasa balado, keju, original, barbeque, pedas, jagung bakar dan sambal terasi. Varian rasa yang banyak diminati oleh konsumen adalah rasa sambal terasi.

b) Harga (Price)

Harga sangat mempengaruhi keputusan konsumen untuk membeli suatu produk atau tidak (Neisia et al., 2018). Harga keripik pisang NVN yang akan dipasarkan tidak berbeda jauh dengan harga yang sudah ada dipasaran. Hal ini dilakukan untuk mendapatkan perhatian dari konsumen dengan rasa yang nikmat, renyah, dan harga yang terjangkau. Harga keripik pisang ini bermacam-macam, mulai dari kisaran Rp5.000,00 hingga Rp40.000,00 per paknya tergantung dari berat keripik pisang tersebut.

c) Place / Lokasi Usaha 
Pemilihan lokasi usaha seringkali menjadi penentu keberhasilan suatu usaha (Fitriyani et al., 2019). Lokasi dari usaha ini kurang strategis karena tempat usaha ini masih sulit dijangkau maka dari itu usaha ini melakukan pemasarannya melalui media social dan secara langsung terjun ke pasar atau dari toko ke toko dan selanjutnya jika usaha ini lancar akan mencari tempat usaha yang lebih strategis.

d) Promotion / Promosi

Promosi merupakan kegiatan pemasaran yang bertujuan menyebarluaskan informasi produk dari produsen (Solihin \& Wibawanto, 2020). Promosi yang dilakukan oleh tim pada pengabdian ini menggunakan sarana media sosial dan terjun langsung kepasar maupun toko. Perkembangan teknologi yang semakin canggih sehingga sarana media sosial dapat sangat membantu dalam memperkenalkan produk tim pengabdian dan menarik daya tarik konsumen.

e) Physical Evidence (Bukti Fisik)

Tempat usaha industri kecil ini memiliki ukuran sekitar 2,5 x 15 m yang berlokasi di Desa Brondong, yang mana merupakan juga rumah pribadi pemilik usaha. Selain itu industri kecil ini memiliki legalitas usaha berupa surat penting seperti surat izin usaha, sertifikasi produksi pangan industri rumah tangga, sertifikat penyuluhan keamanan pangan, dan sertifikat laik sehat.

f) People (Sumber Daya Manusia)

Seluruh kegiatan operasional usaha ini yang tim pengabdian dapati hanya dijalankan oleh dua orang yaitu Ibu Novi Rahayu dan suaminya. Beliau tidak memiliki karyawan sejak usaha ini pertama kali beroperasi.

Kepuasan pelanggan merupakan prioritas utama tim pengabdian, sehingga hubungan dengan konsumen dapat selalu terjaga. Industri keripik NVN selalu menjaga kualitas pelayanan dan citra rasa agar konsumen akan terus datang kembali untuk membeli produk ini. Tim pengabdian berusaha agar usaha yang dijalankan dapat terus berjalan dalam jangka waktu pendek dan jangka waktu panjang.

g) Process (Proses)

Dalam menjalankan usaha ini tim pengabdian mengutamakan kebersihan dan higienitas produk yang dibuat dalam proses produksinya. Selain itu tim pengabdian juga memperhatikan dalam pelayanan terhadap konsumen agar konsumen puas, percaya dan setia terhadap produk tim pengabdian (loyalitas konsumen). 
ABDI WIRALODRA

JURNAL PENGABDIAN KEPADA MASYARAKAT
ISSN 2656-5501 (Print)

ISSN 2714-8041 (Online)

Berdasarkan penjelasan di atas, melalui menerapkan tujuh aspek pemasaran ini diharapkan dapat meningkatkan jumlah permintaan atau pesanan dari produk ini. Prosesnya semestinya membutuhkan waktu dan tidak dapat dimungkiri bahwa tim pengabdian tidak mampu melaksanakan semua pada rencana-rencana yang telah dipaparkan.

\section{Desain Produk}

Desain Produk sebagai kata kerja adalah membuat produk baru untuk dijual kepada pelanggannya atau sebuah koefisien yang sangat luas dan generasi yang efektif serta pengembangan ide melalui proses yang mengarah pada produk baru. Jadi, ini adalah aspek utama dari pengembangan produk baru(Rachman \& Santoso, 2015).

Desain produk sebagai kata benda: himpunan property artefak, yang terdiri dari property diskrit bentuk (yaitu, estetika barang atau jasa yang bewujud) dan fungsi (yaitu kemampuannya) bersama dengan sifat holistic dari yang terintegrasi bentuk dan fungsi sebagai berikut.

Tren Dalam Desain Produk

Desainer produk perlu mempertimbangkan semua detail cara orang menggunakan dan menyalahgunakan objek, produk yang salah, kesalahan yang dibuat dalam proses desain, dan cara yg diinginkan di mana orang ingin mereka dapat menggunakan objek. Banyak desain baru akan gagal dan banyak yang bahkan tidak berhasil dipasarkan. Beberapa desain itu sendiri bisa sangat membuat frustasi biasanya membutuhkan 5 atau 6 kali percobaan untuk mendapatkan desain produk yang benar. Sebuah produk yang gagal di pasar untuk pertama kalinya dapat diperkenalkan kembali ke pasar 2 kali lagi. Jika terus gagal, produk tersebut kemudian dianggap mati karena pasar percaya itu gagal.

Semua jenis desain produk secara jelas terkait dengan kesehatan ekonomi sektor manufaktur. Inovasi memberikan banyak dorongan kompetitif untuk pengembangan produk baru, dengan teknologi baru yang seringkali membutuhkan interpretasi desain baru.

\section{Proses Desain Produk}


Proses desain produk telah mengalami lompatan besar dalam evolusi selama beberapa tahun terakhir dengan munculnya dan adopsi percetakan 3D. Proses desain produk, seperti yang diungkapkan oleh Koberg dan Bagnell, biasanya melibatkan tiga aspek utama : analisis, konsep, perpaduan. Mitra disini memiliki 5 tujuan penting dalam proses desain produk, yaitu:
a. Utility (Kegunaan)
b. Appearance (Tampilan)
c. Easy to maintenance (Kemudahan pemeliharaan)
d. Low cost (Biaya rendah)
e. Communication (Komunikasi) atau desain produk yang memberikan informasi terkait perusahaan atau produk itu sendiri.

Desain produk sendiri secara objek memiliki fungsi sebagai berikut. Antara lain :

a. Menjadi identitas (brand) dari produk

b. Melindungi produk (quality control)

c. Menambah nilai produk

Desain produk (kemasan dan label) mengambil contoh produk keripik pisang berukuran $15 \mathrm{~cm}$ dengan berat bersih 100 gram. Menggunakan kemasan plastik transparan yang diberi label "Keripik Pisang NVN" pada bagian atasnya. Desain produk seperti ini sangat umum digunakan oleh kebanyakan industri makanan rumah tangga. Sehingga, secara sederhana desain seperti ini sudah cukup bagus, aman, dan hemat biaya.

Namun desain label keripik pisang yang lama terlalu simpel dan kurang menarik di pasaran maka perlu didesain ulang yang lebih menarik. Pembahasan tentang bagaimana desain label baru akan di bahas selanjutnya. Dengan desain label yang baru diharapkan akan menarik minat konsumen.

\section{B. Metode}

Metode yang digunakan dalam pelaksanaan praktek kerja lapangan ini adalah dengan metode partisipatif. Metode partisipatif adalah metode dimana tim pengabdian bersama mitra ikut serta dalam proses awal hingga akhir(Akbar et al., 2018). Pada pengabdian ini penulis ikut berpartisipasi bekerja di Usaha Kecil 


\section{ABDI WIRALODRA}

JURNAL PENGABDIAN KEPADA MASYARAKAT
ISSN 2656-5501 (Print)

ISSN 2714-8041 (Online)

Menengah (UKM) milik Ibu Novi yakni Keripik Pisang (NVN). Pengambilan data dilakukan melalui observasi dan wawancara. Data yang diperoleh berupa data primer dimana data tersebut diperoleh langsung dari responden. Metode wawancara dilakukan dengan cara bertanya langsung dengan pemilik keripik pisang. Sedangkan metode observasi dilakukan dengan cara mengamati langsung proses pembuatan keripik pisang.

\section{Penggunaan Media Sosial}

Penggunaan media sosial ini dalam proses pemasaran Keripik Pisang (NVN) milik Ibu Novi ini memiliki hambatan dalam menggunakan media sosial. Pertama, pemilik beranggapan bahwa media sosial masih terbilang sulit untuk memasarkan nya. Kedua, ketakutan akan proses penerimaan dalam jumlah banyak sedangkan dalam proses produksinya tidak setiap waktu.

Melihat permasalahan ataupun hambatan yang ada di tempat Usaha Kecil Mengah (UKM) milik Ibu Novi yakni Keripik Pisang (NVN) ini tim pengabdian menawarakan berbagai solusi maupun bantuan yakni menggunakan media sosial seperti Whatsapp, Instagram, dan Facebook dalam proses pemasaran dengan maksud membantu mempromosikan dan memberikan pemahaman tentang cara penggunaan media sosial untuk menjual suatu barang dan/atau jasa.

\section{Mendesain Produk}

Desain label dalam produk yang digunakan oleh keripik pisang ini masih terbilang simple. Untuk itu tim pengabdian sebagai penulis yang melakukan praktek kerja lapangan diusaha tersebut merasa perlu adanya perubahan atau inovasi dalam penggunaan desain.

\section{Hasil dan Pembahasan}

Pada 11 Agustus 2020, tim pengabdian mendatangi IKM Keripik Pisang NVN yang beralamat di Desa Brondong, Blok Bondol dan pemiliknya bernama Ibu Novi Rahayu. Tim pengabdian berbicara banyak tentang IKM ini. Kemudian tim pengabdian bertanya apakah tim pengabdian diterima untuk melaksanakan kegiatan PKL di tempat ini atau tidak. Lalu Ibu Novi menyetujui permintaan tim pengabdian dan mengizinkan untuk melaksanakan kegiatan PKL ini. Dikarenakan di IKM ini 
produksinya tidak menentu jadi tim pengabdian tidak setiap waktu untuk berkunjung. Hanya ketika ada kegiatan produksi saja.

Pada hari yang sama ketua Kelompok 6 mengabari DPL tim pengabdian, Ibu Nunung, untuk menanyakan apakah tim pengabdian dapat melaksanakan PKL di IKM tersebut. Kemudian Ibu Nunung menyetujuinya, asalkan ada surat izin usaha atau sejenisnya yang dapat dijadikan alat bukti bahwa IKM tersebut telah terdaftar dan berizin. Beberapa hari kemudian Ibu Novi dapat menunjukkan surat izin usahanya kepada tim pengabdian, dan setelah itu kegiatan PKL tim pengabdian bisa dimulai. Tetapi, selama satu minggu tim pengabdian tidak mendapat kabar apapun dari Ibu Novi dikarenakan beliau tidak sedang memproduksi keripik dan memiliki kesibukan lain.

Pada 13 Agustus tim pengabdian menyempatkan diri untuk melakukan diskusi membahas tindak lanjut terkait dengan bagaimana tim pengabdian melaksanakan PKL dan pengerjaan laporan PKL.

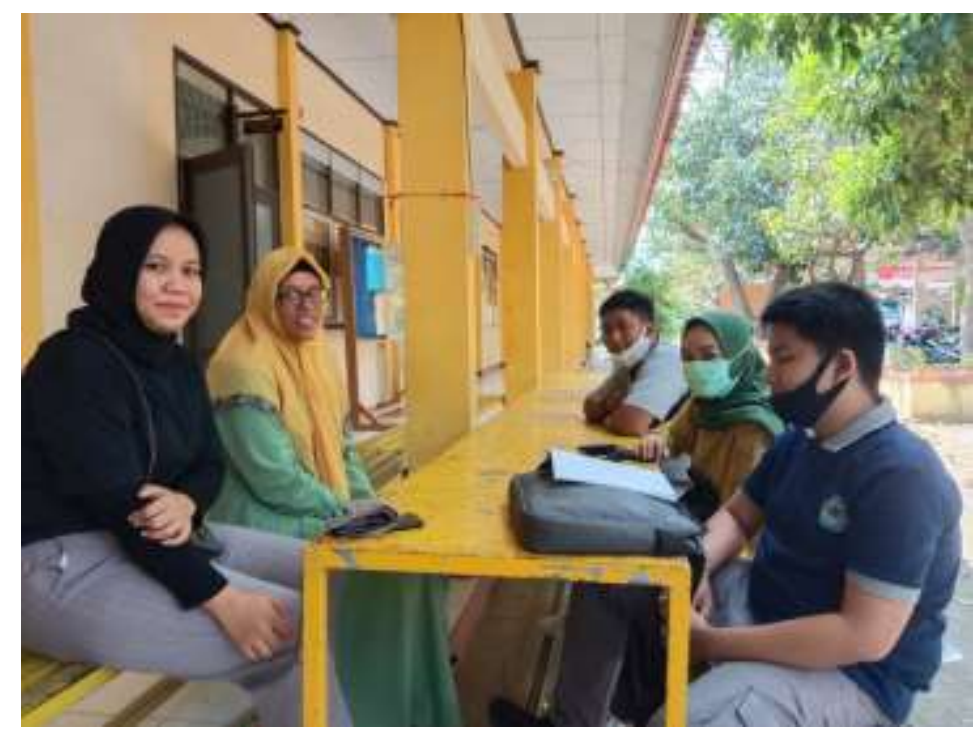

Gambar 1. Diskusi Bersama Tim Pengabdian

Pada tanggal 22 Agustus, Ibu Novi mengabarkan bahwa pada hari ini beliau batal memproduksi keripik untuk alasan yang tidak disebutkan. Untuk kegiatan produksi akan diganti ke hari lain dan akan segera dikabarkan kembali.

Tanggal 23 Agustus, tim pengabdian berkumpul di kampus untuk mendiskusikan laporan kegiatan dan sedikit banyak mengerjakan beberapa hal 
seperti membuat rancangan laporan dan mencatat hal-hal penting untuk didiskusikan bersama pemilik IKM Keripik Pisang NVN.

Tanggal 25 Agustus tim pengabdian diminta oleh Ibu Novi untuk datang ke IKM-nya untuk mendiskusikan persiapan produksi. Pada pukul 13.00 tim pengabdian pun datang ke sana. Kesimpulan pada pertemuan itu adalah untuk produksi keripik akan dilaksanakan pada 27 Agustus. Estimasi produksi keripik adalah 120 bungkus, kemasan 100 gram. Tim pengabdian diminta mendokumentasikan seluruh proses tanpa video dan tim pengabdian menyetujuinya. Untuk foto pada pertemuan ini tidak terambil, karena pemilik menolak untuk difoto.

Hari Kamis, tanggal 27 Agustus tim pengabdian akhirnya dapat mendokumentasikan kegiatan produksi IKM ini. Sebelum dimulai, tim pengabdian berbicara sedikit atau me-review tentang bagaimana kegiatan produksi berlangsung dan bagaimana sudut foto yang akan ditampilkan. Produksi dimulai dengan mencari dan membeli pisang sebagai bahan baku dari petani terdekat. Ibu Novi hanya menggunakan produk pisang lokal Indramayu untuk digunakan. Selanjutnya pisang dikupas hingga bersih. Pisang kemudian direndam kurang lebih 10-15 menit. Setelah itu pisang diiris tipis dan digoreng di dalam wajan berisi minyak panas selama 1-2 menit saja (tergantung ketebalan dan jumlah pisang). Setelah itu pisang yg telah digoreng cukup ditiriskan seperti biasa dan dimasukkan pada bungkus plastik besar ketika sudah dingin. Proses pengemasan kali ini menggunakan bungkus ukuran 100 gram dengan varian rasa jagung bakar. Pisang disusun secara rapi pada bungkus, ditimbang dengan berat 110 gram, diberi bumbu jagung bakar kemudian diberi label keripik dan dipres menggunakan alat pres listrik. Tanggal 2 September, tim pengabdian kembali mengunjungi rumah Ibu Novi bersama DPL tim pengabdian untuk berbincang dan melakukan survei tempat PKL. Pada pertemuan ini Ibu Novi bercerita dan menjelaskan tentang kegiatan-kegiatan tim pengabdian selama melaksanakan PKL di IKM nya kepada Ibu Nunung. Program kerja tim pengabdian yaitu Label dan Pasar. Dari sekian banyak permasalahan yang telah diuraikan pada bab 1 , tim pengabdian menentukan bahwa permasalahan yang sanggup tim pengabdian usahakan solusinya yaitu pemasaran dan label keripik. Pada program kerja label, tim pengabdian berusaha membuat sebuah label baru 
yang diperkirakan dapat menarik minat pelanggan untuk membeli produk keripik pisang ini. Label yang tim pengabdian buat menggunakan sedikit gambar kartun dan didominasi dengan warna putih dan kuning untuk menambah kesan ceria dan berwarna. Dari sebelumnya yang hanya label berisi tulisan saja dan tidak di print tetapi label yang difotokopi. Tim pengabdian berharap label baru yang tim pengabdian buat digunakan seterusnya oleh pemilik IKM ini dan dapat menarik minat konsumen lebih banyak.

Pada program kerja pemasaran tim pengabdian mencoba membantu mengusahakan untuk memasarkannya pada beberapa tempat dan mempromosikannya pada media sosial pilihan yaitu Whatsapp. Tim pengabdian mengunjungi Uyi Futsal yang berlokasi di Jl. Pahlawan, Margadadi, Kec. Indramayu, Kabupaten Indramayu, Jawa Barat. Tim pengabdian menawarkan produk keripik ini dan disetujui oleh pemiliknya. Keripik ini tim pengabdian jual dengan harga Rp8.000,00. Setelah itu tim pengabdian mempromosikan keripik ini melalui Whatsapp dengan harga yang sama

Pembaharuan desain label ini selain merubah warna dan bentuk tulisan tim pengabdian juga menambah gambar pisang didalam labelnya.

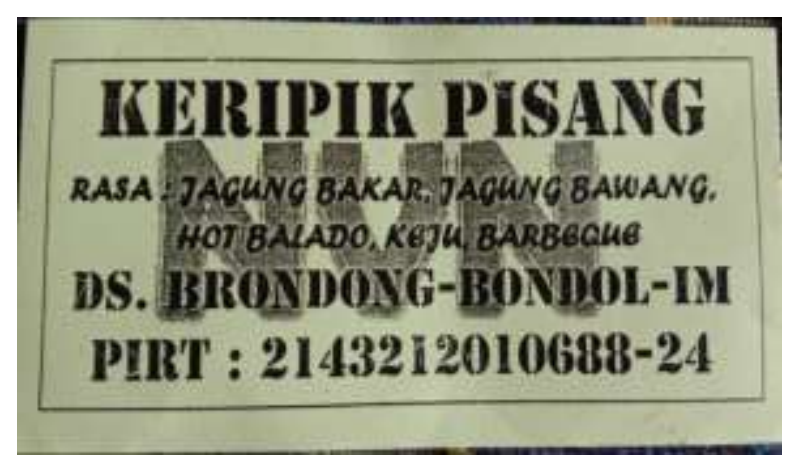

Gambar 2. Label Keripik Pisang NVN

Gambar 2 merupakan tampilan label keripik pisang NVN yang lama. Bahan dari kertas, tidak ada background dan berwarna hitam putih. Label ini dinilai kurang menarik konsumen. Keripik yang sudah siap dipasarkan hanya dimasukkan ke dalam plastik dan distaples. 


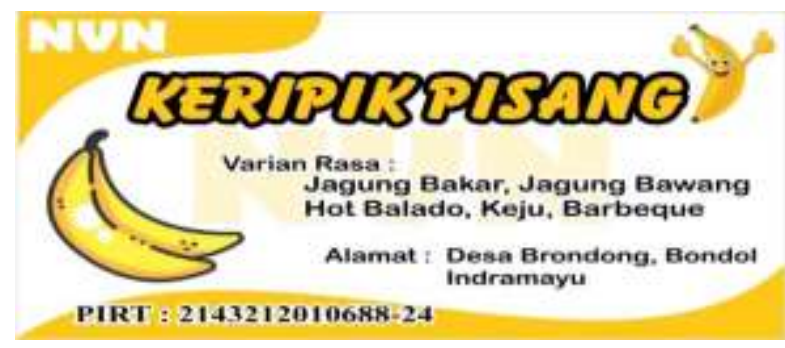

Gambar 3. Desain Label Baru Keripik Pisang NVN

Gambar 3 merupakan label keripik pisang NVN yang baru, tampilan lebih berwarna, ada gambar, dan lebih menarik. Dengan tampilan ini diharapkan dapat memikat konsumen untuk membeli kan mengkonsumsi kripik pisang NVN.

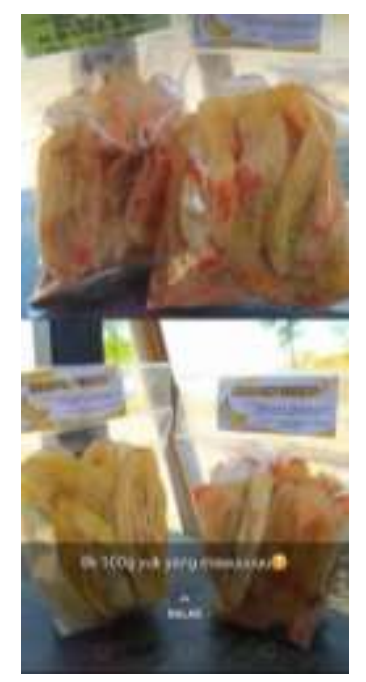

Gambar 4. Promosi/Pemasaran Melalui Media Sosial

Gambar 4 merupakan promosi melalui WhatsApp, Instagram, dan facebook. Harapan tim, dengan promosi di media social dapat menambah pemasukan Ibu Novi dan dapat mengembangkan industri keripik pisang NVN.

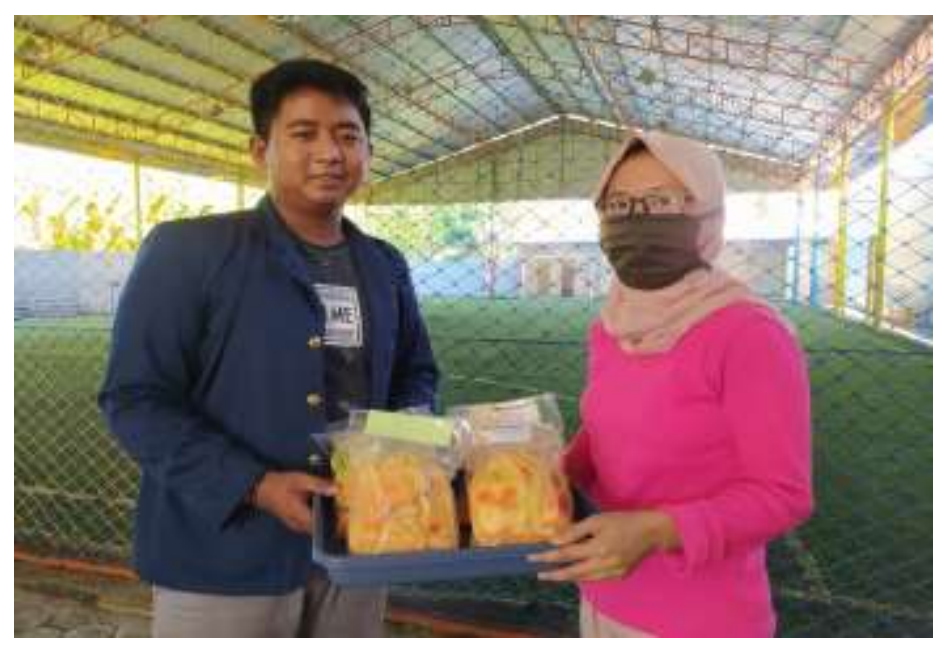

Gambar 5. Pemasaran Pada Uyi Futsal 
Selain melalui media sosial, tim pengabdian juga membantu pemasaran kripik pisang NVN melalui menitipkan keripik pisang ke tempat - tempat berkumpul dan tempat makan. Hal ini dilakukan untuk mendorong keberlangsungan usaha kripik pisang NVN.

\section{Laporan Keuangan IKM Keripik Pisang NVN}

Berikut ini merupakan data yang telah diolah yang diperoleh dari catatan keuangan IKM Keripik Pisang NVN yang dikeluarkan setiap hendak melakukan produksi saja. Bukan merupakan catatan rutin seperti bulanan atau tahunan. Perkiraan jumlah produksi sebanyak 120 pcs dengan harga Rp5.000,00/pcs.

Tabel 1. Jurnal Umum Keripik Pisang NVN 27 Agustus 2020

\begin{tabular}{lllr}
\hline No. & \multicolumn{1}{c}{ Akun } & \multicolumn{2}{c}{ Daldo } \\
& & \multicolumn{1}{c}{ Kredit } \\
\hline 1. & Pisang $(50 \mathrm{Kg})$ & $\mathrm{Rp} 200.000,00$ & \\
& Minyak (10 Kg) & Rp120.000,00 & \\
Bumbu Siap Pakai (2 Kg) & Rp86.000,00 & \\
Plastik Kemasan (1 pak) & Rp36.000,00 & \\
Gas Elpiji (2 tabung) & Rp50.000,00 & \\
Label (120 lbr) & Rp2.000,00 & \\
Kas & & Rp494.000,00 \\
Kas & Rp600.000,00 & \\
Pendapatan & & Rp600.000,00 \\
Total & Rp1.094.000,00 & Rp1.094.000,00 \\
\hline
\end{tabular}

Tabel 2. Laporan Laba Rugi Keripik Pisang NVN 27 Agustus 2020

\begin{tabular}{ll}
\hline Kegiatan & Nominal \\
\hline Pendapatan Bersih & Rp600.000,00 \\
Harga Pokok & $\underline{\text { Rp494.000,00 }}$ \\
Penjualan & \\
Laba Sebelum Pajak & Rp106.000,00 \\
Penghasilan & \\
Pajak Penghasilan & $\underline{\text { Rp530,00 }}$ \\
Laba Bersih & Rp105.470,00 \\
\hline
\end{tabular}


Setelah menggunakan metode partisipatif dalam pelaksanaan praktek kerja lapangan ini tim pengabdian selaku penulis dapat menguraikan bahwa dalam evaluasi pelaksanaan program yang tim pengabdian lakukan antara lain :

1. Dalam penggunaan media sosial

Dalam pelaksanaan program ini sendiri pengunaan media sosial untuk proses pemasaran yakni dari usaha nya sendiri mendapatkan respon yang minim dikarenakan pemilik usaha mengatakan akan banyak resiko yang akan dihadapi.

2. Pembaharuan /atau inovasi label

Dalam pelaksaaan program ini respon dari pemilik usaha yakni sangat menerima hasil pembaharuan desain yang tim pengabdian perbarui. Dikatakan bahwa desain label yang satu ini memiliki sebuah gambar yang diharapkan sangat lebih menarik minat konsumen dibanding desain label sebelumnya.

Metode dan Penerapan Teknologi pada IKM

Metode dalam penerapan teknologi yang ada di Usaha Kecil Menengah (UKM) milik Ibu Novi yakni Keripik Pisang (NVN) ini sendiri memiliki beberapa alat teknologi dalam menunjang proses produksi pembuatan keripik pisang seperti pemotong pisang, timbangan manual, dan mesin pres dalam pengemasan produk. Pada prosedur kerja di tempat produksi milik Ibu Novi yakni Keripik Pisang (NVN) ini sendiri dalam pembagian kerjanya yaitu kepala keluarga (Bapak) bertugas mencari bahan-bahan dan melakukan proses pembuatan keripik pisang. Sedangkan Ibu Novi bertugas melakukan pengemasan dan pemasaran.

Dalam metode partisipatif kali ini tim pengabdian selaku penulis yang terjun langsung dalam melaksanakan praktek kerja lapangan di tempat pembuatan keripik pisang ini mengaku cukup puas dengan hasil dari metode yang tim pengabdian pilih. Karena, pemilik tempat pembuatan keripik pisang tersebut banyak memberikan berbagai informasi dimulai dari sejarah berdiri nya, pihak-pihak yang terlibat, proses pembuatan, dan proses pemasaran.

Hasil dari pengabdian ini adalah masih belum maksimalnya pendapatan IKM ini. Hal ini dapat dilihat dari keuntungan yang dihasilkan dalam satu hari belum maksimal. Pemasaran yang masih belum maksimal juga menjadi penyebab belum 
optimalnya usaha ini. Hasil pengabdian ini sependapat dengan Wibowo et al., (2015), bahwa dengan analisis strategi pemasaraan yang baik maka akan berdampak pada peningkatan pendapatan. Hal ini selaras dengan pendapat (Barusman, 2014), bahwa bauran pemasaran sangat berpengaruh terhadap kepuasan pelanggan. Dengan demikian masih diperlukan optimalisasi pemasaraan oleh Ibu Novi supaya produk yang dihasilkan dapat lebih dikenal dan berkembang.

Dalam keberlanjutan program yang telah dilakukan tim pengabdian harap sebagai penulis bahwa program yang tim pengabdian kerjakan akan mendapat pertimbangan dari pemilik usaha untuk kedepannya dalam mengimplementasikan proses penggunaan media sosial maupun tentang pembaharuan label kemasan keripik pisang tersebut.

\section{Kesimpulan}

Kegiatan PKL tim pengabdian yang dilaksanakan pada IKM Keripik Pisang NVN berjalan dengan lancar, namun ada beberapa hambatan tentunya. Sebagai informasi, kegiatan ini berlangsung selama sebulan lebih atau lebih tepatnya 40 hari sejak pembukaan kegiatan. Selama itu dilalui dengan cukup banyak kegiatan dan persiapan sebelum dokumentasi utuh pada saat kegiatan produksi, dikarenakan sedikitnya waktu produksi dari IKM Keripik Pisang NVN ini. Sehingga tim pengabdian pun tidak bisa banyak mendokumentasikan hal tersebut. Hambatan lain yaitu ketika pada minggu pertama kegiatan PKL tim pengabdian tidak menerima info apapun dari Ibu Novi Rahayu, maka selama waktu itu tidak ada kegiatan apapun pula dari tim pengabdian.

Desa Brondong sendiri terletak cukup jauh jika dari Kecamatan Indramayu dengan akses jalan yang tidak baik dan cukup kecil, tetapi untungnya masih dapat dicapai dengan menggunakan motor ataupun mobil. IKM Keripik Pisang NVN beroperasi di rumah pribadi Ibu Novi Rahayu yang kondisinya sebenarnya tidak memadai dan kurang higienis. Mengingat ada beberapa ayam yang berkeliaran dan polusi udara disekitar IKM yang disebabkan oleh bau bahan bakar solar yang digunakan nelayan-nelayan sekitar.

Terkait dengan program kerja yang tim pengabdian laksanakan perlu diakui

tidak memberikan hasil yang maksimal. Pada desain label keripik yang baru 


\section{ABDI WIRALODRA \\ ISSN 2656-5501 (Print) \\ JURNAL PENGABDIAN KEPADA MASYARAKAT \\ ISSN 2714-8041 (Online)}

belum membuktikan adanya peningkatan jumlah pesanan ataupun permintaan dari produk keripik pisang ini. Penyebabnya masih belum dapat diketahui karena sejak didesainnya label yang baru, penggunaannya bersifat sementara dan usianya baru berkisar 2 minggu.

Kemudian, tentang pemasaran. Tim pengabdian pada dasarnya melakukan 2 jenis pemasaran yaitu komersial dan daring. Pemasaran komersial terbukti sukses dengan disetujuinya pemilik Uyi Futsal untuk tim pengabdian menjual keripik tersebut pada kantinnya. Sedangkan pemasaran daring melalui media sosial Whatsapp tidak menghasilkan permintaan apapun sejak iklan diposting. Hal inilah yang perlu diperhatikan dan dievaluasi tentang bagaimana keefektifan penggunaan media sosial sebagai sarana pemasaran daring.

Terakhir, kegiatan PKL ini terbilang sukses. Karena dengan metode-metode pemasaran sederhana dengan proses produksi yang masih sederhana pula maka jumlah permintaan dapat ditingkatkan. Maksudnya, dengan metode pemasaran "tradisional" cukup untuk meningkatkan keuntungan IKM. Tim pengabdian sepakat bahwa penggunaan ranah daring / online dalam pemasaran produk ini kurang efektif karena belum memenuhi standardisasi produk masyarakat media sosial (netizen) karena menggunakan metode "tradisional" saja untuk memperkuat jaringan pemasarannya.

\section{E. Ucapan Terima kasih}

Terima kasih kepada Ketua LPPM Universitas Wiralodra yang telah memberikan ijin kepada tim untuk melakukan pengabdian masyarakat. Terima kasih kepada Dekan Fakultas ekonomi yang telah memfasilitasi tim saat pelaksanaan pengabdian. Terima kasih kepada semua pihak yang telah membantu kegiatan pengabdian ini.

\section{Daftar Pustaka}

Akbar, M. F., Suprapto, S., \& Surati, S. (2018). Partisipasi Masyarakat Dalam Perencanaan Pembangunan di Desa Jatimulya Kabupaten Boalemo. Publik: (Jurnal Ilmu Administrasi), 6(2), 135. https://doi.org/10.31314/pjia.6.2.135142.2017

Barusman, A. R. P. (2014). ANALISIS STRATEGI BAURAN PEMASARAN TERHADAP KEPUASAN KONSUMEN DI BUBUR GABE BANDAR LAMPUNG. Jurnal Manajemen Dan Bisnis, 4(2), 179-196. 
Fitriyani, S., Murni, T., \& Warsono, S. (2019). Pemilihan Lokasi Usaha Dan Pengaruhnya Terhadap Keberhasilan Usaha Jasa Berskala Mikro Dan Kecil. Managament Insight: Jurnal Ilmiah Manajemen, 13(1), 47-58. https://doi.org/10.33369/insight.13.1.47-58

Ihza, K. N. (2020). DAMPAK COVID-19 TERHADAP USAHA MIKRO KECIL DAN MENENGAH (UMKM) ( Studi Kasus UMKM Ikhwa Comp Desa Watesprojo, Kemlagi, Mojokerto). Jurnal Inovasi Penelitian, 1(7), 13251330.

Kore, E. L. R., \& Septarini, D. F. (2018). ANALISIS KINERJA USAHA MIKRO KECIL DAN MENENGAH (UMKM) (Studi Kasus Pada UMKM Sektor Industri Kecil Formal Di Kabupaten Merauke). Jurnal Ilmu Ekonomi \& Sosial, 9(1), 22-37. https://doi.org/10.35724/jies.v9i1.703

Maya, S., \& Yohanna, L. (2018). Identification of Problems and Solution of The Micro Small Middle Entreprise with Nvivo-Software. Sosio E-Kons, 10(2), 121. https://doi.org/10.30998/sosioekons.v10i2.2606

Neisia, T. C., Kalangi, J. A. F., \& Walangitan, O. (2018). Pengaruh Harga Terhadap Penjualan Produk Motor Yamaha Mio Pada PT. Hasjrat Abadi Outlet Karombasan Manado. Jurnal Administrasi Bisnis, 6(3), 35-43.

Pratiwi, S. D., \& Suriani, L. (2017). Strategi pemasaran Produk Rangka Atap Baja Ringan pada PT. Hari Rezeki kita Semua pekanbaru. Jurnal Valuta, 3(2), 241275.

Rachman, B. J., \& Santoso, S. B. (2015). Analisis Pengaruh Desain Produk dan Promosi terhadap Kemantapan Keputusan Pembelian yang Dimediasi oleh Citra Merek (Studi pada Customer Distro Jolly Roger Semarang). Diponegoro Journal of Management, 4(1), 1-15.

Ratnasari, A., \& Kirwani. (2013). Peranan Industri Kecil Menengah (IKM) Dalam Penyerapan Tenaga Kerja di Kabupaten Ponorogo. Jurnal Pendidikan Ekonomi, 1(3), 1-17.

Rosita, R. (2020). Pengaruh Pandemi Covid-19 Terhadap Umkm Di Indonesia. Jurnal Lentera Bisnis, 9(2), 109. https://doi.org/10.34127/jrlab.v9i2.380

Sari, K. M. P., \& Kusumadewi, N. M. W. (2016). Analisis Pengaruh Bauran Pemasaran Terhadap Volume Penjualan Pada PT . Hatten Bali di Kota Denpasar. E-Jurnal Manajemen Unud, 5(5), 3080-3105.

Solihin, D., \& Wibawanto, E. (2020). Pengaruh Kualitas Pelayanan, Harga, Dan Promosi Terhadap Keputusan Pelanggan Dalam Memilih Klub Basket Satria Indonesia Tangerang Selatan. Jurnal Pemasaran Kompetitif, 3(3), 30. https://doi.org/10.32493/jpkpk.v3i3.4738

Wibowo, D. H., Arifin, Z., \& Sunarti. (2015). ANALISIS STRATEGI PEMASARAN UNTUK MENINGKATKAN DAYA SAING UMKM (Studi pada Batik Diajeng Solo). Jurnal Administrasi Bisnis (JAB), 29(1), 59-66.

Widyastuti, S. (2017). Manajemen Komunikasi Pemasaraan Terpadu. FEB_UP Press: Jakarta. https://doi.org/10.1300/j054v03n02_03 